\title{
Effect of plant secondary metabolites on legume pod borer, Helicoverpa armigera
}

\author{
Abdul Rashid War • Michael Gabriel Paulraj • \\ Barkat Hussain • Abdul Ahad Buhroo • \\ Savarimuthu Ignacimuthu $\cdot$ Hari Chand Sharma
}

Received: 14 November 2012/Accepted: 22 February 2013/Published online: 16 March 2013

(C) Springer-Verlag Berlin Heidelberg 2013

\begin{abstract}
The effect of various flavonoids, lectins and phenyl $\beta$-D-glucoside on larval survival, weights and the activities of digestive (total serine protease and trypsin) and detoxifying [esterase and glutathione- $S$-transferase] enzymes of Helicoverpa armigera larvae at 5 and 10 days after treatment (DAT) was studied through diet incorporation assay. Flavonoids (quercetin, cinnamic acid, caffeic acid, chlorogenic acid, catechin, trihydroxyflavone, gentisic acid, ferulic acid, protocatechuic acid and umbelliferone) were incorporated in artificial diet at 100, 500 and 1000 ppm, lectins: groundnut leaf lectin (GLL), concavalin (ConA) and phenyl $\beta$-D-glucoside at 2.5 and $5 \mu \mathrm{g} \mathrm{mL}^{-1}$. Flavonoids such as chlorogenic acid, caffeic acid and protocatechuic acid at $1,000 \mathrm{ppm}$ were more toxic to $H$. armigera larvae at 10 DAT than quercetin, catechin, cinnamic acid, trihydroxyflavone, gentisic acid, ferulic acid and umbelliferone. Larval growth and development were significantly reduced in $\mathrm{H}$. armigera larvae fed on a diet
\end{abstract}

Communicated by J. Gross.

A. R. War · H. C. Sharma $(\bowtie)$

International Crops Research Institute for the Semi-Arid Tropics (ICRISAT), Patancheru 502324, Andhra Pradesh, India

e-mail: H.Sharma@cgiar.org

A. R. War · M. G. Paulraj · S. Ignacimuthu

Entomology Research Institute, Loyola College, Chennai 600034, Tamil Nadu, India

B. Hussain

Division of Entomology, Sheri-Kashmir University of Agricultural Sciences and Technology (SKUAST-K), Shalimar, Srinagar, Jammu and Kashmir, India

A. A. Buhroo

Division of Entomology, Department of Zoology, University of Kashmir, Srinagar 190006, Jammu and Kashmir, India with GLL and ConA at $5 \mu \mathrm{g} \mathrm{mL}^{-1}$ compared to the larvae fed at 2.5 and $1.25 \mu \mathrm{g} \mathrm{mL}^{-1}$ concentrations. The enzyme activities of the larvae were significantly reduced in flavonoid-treated diets. The flavonoids such as chlorogenic acid, caffeic acid, gentisic acid, trihydroxyflavone, catechin and protocatechuic acid, and lectins, GLL and ConA can be utilized in insect control programs.

Keywords Secondary metabolites - Flavonoids . Lectins · Midgut enzymes · Helicoverpa armigera

\section{Introduction}

Plants produce a number of defensive secondary metabolites in response to insect herbivory, pathogen infection and other stresses. The secondary metabolites do not affect the normal growth and development of plant, but reduce the palatability of the plant tissues to the herbivores (Boerjan et al. 2003). Among the secondary metabolites, plant phenols constitute one of the most common and widespread groups of defensive compounds, which play a major role in host plant resistance against herbivores, including insects (Sharma et al. 2009; Usha Rani and Jyothsna 2010; Ballhorn et al. 2011). Qualitative and quantitative alterations in secondary metabolites and increase in activities of oxidative enzymes in plants in response to insect attack is a general phenomenon (Maffei et al. 2007; Barakat et al. 2010; He et al. 2011; War et al. 2012). Phenols mediate both direct and indirect defenses. The direct defenses are mediated by their toxic or deterrent activity against insect pests and the indirect defenses by their effect on natural enemies of insect pests (Karban and Baldwin 1997; Heil 2008; Sharma et al. 2009; Barakat et al. 2010; War et al. 2012). Condensed tannins are the potent plant defensive compounds implicated against insect pests and have been 
reported to reduce the growth and survivorship in many insect pests (Grayer et al. 1992; Sharma et al. 2009). Flavonoids play a central role in various facets of plant life, especially in plantenvironment interactions (Treutter 2006). These defend plants against biotic and abiotic stresses, including ultraviolet radiation, pathogen infection and herbivore damage (Simmonds 2003; Treutter 2006). Flavonoids are divided into various classes that include anthocyanins, flavones, flavonols, flavanones, dihydroflavonols, chalcones, aurones and flavans (Simmonds 2003; Treutter 2006).

Evidence suggests the role of flavonoids in plant defense against insect pests (Mallikarjuna et al. 2004; Treutter 2006; Salvador et al. 2010; Atteyat et al. 2012). Isoflavonoids (judaicin, judaicin-7-O-glucoside, 2-methoxyjudaicin, and maackiain) isolated from the wild relatives of chickpea act as antifeedants against $H$. armigera at 100 ppm (Simmonds and Stevenson 2001). The flavonoids, quercetin dehydrate, rutin hydrate and naringine at $1,000 \mathrm{ppm}$ showed the mortality of 85, 93 and $86 \%$, respectively, in Eriosoma lanigerum (Haus.) in a twig dip assay (Atteyat et al. 2012). In addition, flavonoids scavenge the free radicals in plants, including reactive oxygen species (ROS), and reduce their formation by chelating metals (Treutter 2006). However, some flavonoids have been found to act as feeding stimulants (van Loon et al. 2002). Lectins are carbohydrate-binding (glyco) proteins and are involved in plant defense against a range of insect pests (Saha et al. 2006; Chakraborti et al. 2009; Vandenborre et al. 2011). The strong insecticidal potential of lectins is attributed to their binding to the membrane glycosyl groups lining the digestive tract of the herbivores (Chakraborti et al. 2009; Vandenborre et al. 2011). The $\beta$-glucosides are the important toxic compounds involved in plant defense against insect pests (Zagrobelny et al. 2004).

Helicoverpa armigera (Hub.) is one of the most important polyphagous pests, which attacks more than 200 plant species throughout the world, and has developed high levels of resistance to most of the chemical insecticides (Sharma et al. 2005). The objective of the present investigation was to study the effect of some flavonoids, lectins and phenyl $\beta$-D-glucoside on the growth and development and midgut enzyme activities of pod borer, $H$. armigera, to be used as a component of integrated pest management (IPM) for this polyphagous pest. This will give us an insight into the mechanism of toxicity of flavonoids and related compounds on insect pests.

\section{Materials and methods}

\section{Chemicals}

The chemicals used in this study were of analytical grade. Ethylene diamine tetra acetic acid (EDTA), sodium dodecyl sulphate (SDS), azocasein, $N$ - $\alpha$-benzoyl- $\mathrm{D}_{\mathrm{L}}$-arginyl- $p$ nitroanilide (BA $p \mathrm{NA})$, glycine, sodium hydroxide $(\mathrm{NaOH})$, naphthyl acetate, fast blue $\mathrm{B}$, Concavalin $\mathrm{A}(\mathrm{ConA})$ reduced glutathione (GSH), phenyl $\beta$-D-glucoside, disodium hydrogen phosphate and sodium dihydrogen phosphate were obtained from Sigma Aldrich, USA. Trichloroacetic acid (TCA) was obtained from Sisco Research Lab., Mumbai, India. 1-chloro-2,4-dinitrobenzene (CDNB) was obtained from HiMedia Pvt. Ltd., Mumbai, India. Acetic acid was obtained from Qualigens Fine Chemicals, Mumbai, India. Flavonoids were obtained from APIN Chemical Ltd., UK.

The biochemical assays were carried out on UV-spectrophotometer Hitachi U-2900 (Hitachi, Japan).

\section{Helicoverpa armigera culture}

Newly emerged first instar larvae were obtained from the laboratory culture at International Crops Research Institute for the Semi-Arid Tropics (ICRISAT), Patancheru, Andhra Pradesh, India.

\section{Bioassay}

The effect of flavonoids on insect growth and development was studied by feeding the larvae on flavonoids incorporated artificial diet. Ten flavonoids: quercitin, cinnamic acid, caffeic acid, chlorogenic acid, catechin, trihydroxyflavone, gentisic acid, ferulic acid, protocatechuic acid and umbelliferone were bioassayed using diet incorporation assay (Narayanamma et al. 2008). The flavonoids were weighed and mixed with the diet $\left(\mathrm{mg} \mathrm{mL}^{-1}\right)$ just after its preparation. Neonates of $H$. armigera were released on the diet containing three concentrations of each flavonoid (100, 500 and $1000 \mathrm{ppm})$. One larva was released in each cell well in a 20-well plastic plate. Four replications were maintained for each treatment with ten larvae in each replication. Larvae fed on untreated diet were maintained as a control. After 5 and 10 days of treatment, larval weights were recorded, while larval survival was computed at 10 days after treatment(DAT). The larvae after 10 days of treatment were used to study the effect of flavonoids on gut enzyme activities such as serine protease, trypsin, esterase (EST) and glutathione-S-transferase (GST).

Groundnut leaf lectin (GLL) and ConA and phenyl $\beta$-Dglucoside were also incorporated into the artificial diet to study their effects on biology of $H$. armigera. The concentrations used were $1.25,2.5$ and $5 \mu \mathrm{g} \mathrm{mL}^{-1}$ of diet. Four replications were maintained for each treatment and ten larvae placed individually in cell wells in each replication. The larvae fed on untreated diet were maintained as a control. At 5 and 10 DAT, larval weights were recorded. Larval survival was recorded at 10 DAT only. At 10 DAT , 
the larvae were used to study insect gut enzymes (EST, GST, trypsin, and serine protease).

Total serine protease assay

The larvae were dissected and midguts extracted in $0.2 \mathrm{M}$ sodium phosphate buffer ( $\mathrm{pH}$ 7.5). The midguts were removed and homogenized in $0.1 \mathrm{M}$ glycine- $\mathrm{NaOH}$ buffer (pH 10), containing $1 \mathrm{mM}$ EDTA. The homogenate was filtered through three layered cheese cloth and centrifuged at $10,000 \mathrm{rpm}$ for $20 \mathrm{~min}$ at $4{ }^{\circ} \mathrm{C}$. The supernatant was collected and used as enzyme source for serine protease and trypsin activity. Serine protease activity of insect midgut was estimated by following the method of Hegedus et al. (2003) using azocasein as a substrate. To $0.04 \mathrm{~mL}$ of midgut supernatant, $0.3 \mathrm{~mL}$ of $1 \%$ azocasein solution (prepared in $0.05 \mathrm{M}$ glycine- $\mathrm{NaOH}$ buffer, $\mathrm{pH} 10$ ) was added. The reaction mixture was incubated at $28{ }^{\circ} \mathrm{C}$ for $15 \mathrm{~min}$, and then $0.34 \mathrm{~mL}$ of $10 \%$ TCA was added to it. The reaction mixture was incubated again for $1 \mathrm{~h}$ at room temperature and centrifuged at 12,000 rpm for $10 \mathrm{~min}$. The supernatant was collected in a separate tube and $0.68 \mathrm{~mL}$ of $1 \mathrm{M} \mathrm{NaOH}$ added to it. Absorbance was read at $495 \mathrm{~nm}$.

Total midgut serine protease activity (SP) was calculated by subtracting the azocasein blank absorbance from sample absorbance divided by incubation time in minutes multiplied by 1,000 .

$\mathrm{SP}=\frac{\mathrm{Abs}_{(\text {sample })}-\mathrm{Abs}_{(\text {blank }}}{\text { Incubation time }(\min )} \times 1,000$

Units are tryptic activity $(\mathrm{mU})$ per min of incubation per $\mathrm{mg}$ insect body weight $\left(\mathrm{mU} \min ^{-1} \mathrm{mg}^{-1}\right.$ protein).

\section{Trypsin assay}

Trypsin activity of the insect midgut was determined as per the method described by Perlmann and Lorand (1970). Larval midgut extract $(0.15 \mathrm{~mL})$ was added to $1 \mathrm{~mL}$ of $1 \mathrm{mM} \mathrm{BApNA}$ (in $0.2 \mathrm{M}$ glycine-NaOH buffer, $\mathrm{pH} 10$ ). The reaction mixture was incubated at $37{ }^{\circ} \mathrm{C}$ for $10 \mathrm{~min}$. The reaction was terminated by adding $0.2 \mathrm{~mL}$ of $30 \%$ acetic acid. Absorbance was read at $410 \mathrm{~nm}$ and the

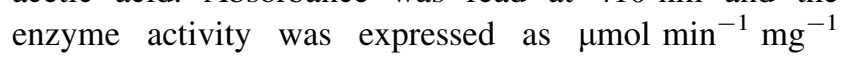
protein.

\section{Esterase assay}

The larvae were dissected in $0.1 \mathrm{M}$ sodium phosphate buffer ( $\mathrm{pH}$ 7.5), then the midguts were removed and homogenized in $0.1 \mathrm{M}$ sodium phosphate buffer ( $\mathrm{pH} 7.5$ ) containing $1 \mathrm{mM}$ EDTA. The homogenate was filtered through three-layered cheese cloth and centrifuged at $12,000 \mathrm{rpm}$ for $15 \mathrm{~min}$ at $4{ }^{\circ} \mathrm{C}$. The supernatant was collected and used as an enzyme source for EST and GST. The EST activity was determined by the following method. To $2 \mathrm{~mL}$ of $1.5 \mathrm{mM}$ 1-naphthyl acetate solution, $0.1 \mathrm{~mL}$ of diluted enzyme sample (10 times with $0.1 \mathrm{M}$ sodium phosphate buffer) was added. This mixture was incubated at $25{ }^{\circ} \mathrm{C}$ for $30 \mathrm{~min}$. The reaction was stopped by addition of Fast Blue B (in $5 \%$ SDS) staining solution. The reaction mixture was incubated for $15 \mathrm{~min}$ and absorbance recorded at $490 \mathrm{~nm}$. The concentration of hydrolyzed substrate was determined from the standard curve of 1-naphthol. Specific activity was expressed as $\mu$ mol of 1-naphthol formed $\min ^{-1} \mathrm{mg}^{-1}$ protein.

Glutathione-S-transferase assay

GST activity was determined using 1-chloro-2,4-dinitrobenzene (CDNB) and reduced GSH as substrates according to Habig et al. (1974) with slight modifications. To $1 \mathrm{~mL}$ of phosphate buffer ( $\mathrm{pH} 7.5), 0.1 \mathrm{~mL}$ of CDNB $(25 \mathrm{mM})$ and $1.6 \mathrm{~mL}$ of distilled water were added. The reaction was started by adding $0.1 \mathrm{~mL}$ of diluted enzyme solution (the stock solution was diluted 10 fold with $0.1 \mathrm{M}$ sodium phosphate buffer, $\mathrm{pH}$ 7.5). The reaction mixture was incubated at $37^{\circ} \mathrm{C}$ for $5 \mathrm{~min}$ and $0.1 \mathrm{~mL}$ of $20 \mathrm{mM} \mathrm{GSH}$ was added. Optical density at $340 \mathrm{~nm}$ was recorded at $30 \mathrm{~s}$ intervals for $3 \mathrm{~min}$. The enzyme activity was calculated with an extinction coefficient of $9.6 \mathrm{mM} \mathrm{cm}^{-1}$ for CDNB. Specific activity was expressed as nmol of CDNB conjugate formed $\mathrm{min}^{-1} \mathrm{mg}^{-1}$ protein.

Statistical analysis

The data were subjected to analysis of variance (ANOVA) using SPSS v15.1 (SPSS, Inc., Chicago, IL, USA). Tukey's test was used to separate the means when the treatment effects were statistically significant $(P \leq 0.05)$.

\section{Results}

Effect on larval growth and development

Among the flavonoids tested, higher larval mortality of $H$. armigera at 10 DAT was observed in larvae fed on diet treated with $1,000 \mathrm{ppm}$ of chlorogenic acid $(42.5 \%)$ followed by caffeic acid (37.2\%), protocatechuic acid $(34.5 \%)$, quercetin $(27.5 \%)$, cinnamic acid $(25.8 \%)$, catechin $(25.0 \%)$ and ferulic acid $(23.3 \%)$ (Table 1). At $500 \mathrm{ppm}$, significantly higher mortality was observed in larvae fed on the diets treated with caffeic acid (26.0\%) and protocatechuic acid (25.5\%) as compared to the rest of the treatments. There were no significant effects on larval mortality at $100 \mathrm{ppm}$. 
Table 1 Mortality (\%) of Helicoverpa armigera larvae fed on diet incorporated with flavonoids at 10 DAT

\begin{tabular}{lrrr}
\hline Treatment & \multicolumn{3}{l}{ Concentration $(\mathrm{ppm})$} \\
\cline { 2 - 4 } & 100 & 500 & 1,000 \\
\hline Quercetin & $17.5 \pm 2.5^{\mathrm{a}}$ & $20.3 \pm 6.4^{\mathrm{a}, \mathrm{b}}$ & $27.5 \pm 4.7^{\mathrm{b}}$ \\
Cinnamic acid & $12.5 \pm 1.4^{\mathrm{a}}$ & $22.0 \pm 4.5^{\mathrm{a}, \mathrm{b}}$ & $25.8 \pm 4.7^{\mathrm{b}}$ \\
Caffeic acid & $15.0 \pm 2.9^{\mathrm{a}}$ & $26.0 \pm 3.1^{\mathrm{a}}$ & $37.2 \pm 5.5^{\mathrm{a}}$ \\
Chlorogenic acid & $15.0 \pm 4.2^{\mathrm{a}}$ & $22.5 \pm 2.1^{\mathrm{a}, \mathrm{b}}$ & $42.5 \pm 6.2^{\mathrm{b}}$ \\
Catechin & $15.8 \pm 4.6^{\mathrm{a}}$ & $20.5 \pm 4.5^{\mathrm{a}, \mathrm{b}}$ & $25.0 \pm 3.5^{\mathrm{b}}$ \\
Trihydroxyflavone & $12.5 \pm 2.2^{\mathrm{a}}$ & $12.5 \pm 3.3^{\mathrm{b}, \mathrm{c}}$ & $15.5 \pm 2.7^{\mathrm{c}}$ \\
Gentisic acid & $13.5 \pm 2.1^{\mathrm{a}}$ & $15.5 \pm 2.4^{\mathrm{b}}$ & $20.5 \pm 3.3^{\mathrm{c}}$ \\
Ferulic acid & $5.5 \pm 1.4^{\mathrm{b}}$ & $17.4 \pm 3.1^{\mathrm{b}}$ & $23.3 \pm 2.8^{\mathrm{b}}$ \\
Protocatechuic acid & $17.5 \pm 1.8^{\mathrm{a}}$ & $25.5 \pm 2.3^{\mathrm{a}}$ & $34.5 \pm 3.6^{\mathrm{a}}$ \\
Umbelliferone & $7.5 \pm 1.1^{\mathrm{b}}$ & $12.5 \pm 1.9^{\mathrm{b}, \mathrm{c}}$ & $17.0 \pm 2.5^{\mathrm{c}}$ \\
Control & $2.5 \pm 0.9^{\mathrm{c}}$ & $2.5 \pm 0.9^{\mathrm{d}}$ & $2.5 \pm 0.9^{\mathrm{d}}$ \\
\hline
\end{tabular}

Values (mean $\pm \mathrm{SD}$ ) with similar letters within a column do not differ significantly at $P \leq 0.05$ (Tukey's HSD test)

$D A T$ days after treatment

At 5 DAT, the larval weights (mg per five larvae) of $H$. armigera fed on diets treated with flavonoids at 100, 500 and $1000 \mathrm{ppm}$ were lower in protocatechuic acid (135.7, 73.3 and 24.4), gentisic acid (103.2, 59.9 and 27.6), chlorogenic acid (101.5, 76.7 and 30.8), caffeic acid (0.04, 0.07 and 0.13$)$, ferulic acid (132.9, 77.5 and 33.8), and trihydroxyflavone $(0.02,0.16$ and 0.19$)$, respectively (Table 2). However, at 10 DAT, caffeic acid showed significantly greater reduction in larval weight (mg per five larvae) (483.1, 250.4 and 129.9), followed by protocatechuic acid (491.2, 273.6 and 181.4) at 100, 500 and
$1000 \mathrm{ppm}$, respectively, than the rest of the treatments. As compared to the larvae fed on untreated control diet, larvae fed on flavonoid-treated diets showed reduced larval weights.

The semi-synthetic diet containing GLL, ConA and phenyl $\beta$-glucoside did not cause significant larval mortality in $H$. armigera (data not shown). However, the larval weights were reduced when these insects were fed on the treated diets. At 5 DAT, $H$. armigera larvae fed on the diets treated with GLL, ConA and phenyl $\beta$-glucoside $\left(5 \mu \mathrm{gL}^{-1}\right.$ each) showed body weight reduction by 4.1-, 3.8- and 2.4-fold, respectively, as compared to those fed on the control diet (Table 3). At 10 DAT, larval weights were reduced by 4.0-, 2.4- and 2.1-fold when fed on the diets treated with GLL, ConA and phenyl $\beta$-glucoside (5 $\mu \mathrm{g} \mathrm{mL}^{-1}$ each), respectively.

Effect on midgut enzyme activities

\section{Effect of flavonoids}

A considerable effect of flavonoids at $1,000 \mathrm{ppm}$ concentration was observed on the serine protease and trypsin activities of $H$. armigera larvae, however, the levels of significance varied across the treatments. Larvae fed on flavonoid-treated diets at $1,000 \mathrm{ppm}$ showed significantly lower levels of serine protease activity in almost all the treatments except in diets with quercetin and umbelliferone as compared to those fed at 100 and $500 \mathrm{ppm}$ concentration of their respective compounds (Fig. 1). Across the treatments, larvae fed on chlorogenic acid, caffeic acid, ferulic acid, gentisic, protocatechuic acid, trihydroxyflavone, catechin and cinnamic acid at 1,000 ppm showed lower serine

Table 2 Weights (mg per five larvae) of Helicoverpa armigera larvae fed on flavonoid incorporated diets at 5 and 10 DAT

\begin{tabular}{|c|c|c|c|c|c|c|}
\hline \multirow[t]{3}{*}{ Treatment } & \multicolumn{3}{|l|}{$5 \mathrm{DAT}$} & \multicolumn{3}{|l|}{$10 \mathrm{DAT}$} \\
\hline & \multicolumn{6}{|c|}{ Concentration (ppm) } \\
\hline & 100 & 500 & 1,000 & 100 & 500 & 1,000 \\
\hline Quercetin & $133.7 \pm 10.5^{\mathrm{b}}$ & $72.3 \pm 7.7^{\mathrm{b}, \mathrm{c}}$ & $54.5 \pm 2.3^{\mathrm{b}}$ & $512.1 \pm 17.7^{\mathrm{c}}$ & $371.4 \pm 10.2^{\mathrm{c}}$ & $261.5 \pm 8.8^{\mathrm{c}, \mathrm{d}}$ \\
\hline Cinnamic acid & $156.0 \pm 13.3^{\mathrm{b}}$ & $91.5 \pm 6.9^{\mathrm{b}}$ & $71.2 \pm 2.9^{\mathrm{b}}$ & $621.2 \pm 9.9^{\mathrm{b}}$ & $492.2 \pm 9.3^{\mathrm{b}}$ & $321.2 \pm 7.4^{\mathrm{b}}$ \\
\hline Caffeic acid & $134.8 \pm 9.3^{b}$ & $74.8 \pm 6.5^{\mathrm{b}, \mathrm{c}}$ & $44.9 \pm 1.6^{\mathrm{b}, \mathrm{c}}$ & $483.1 \pm 10.4^{\mathrm{c}}$ & $250.4 \pm 8.0^{\mathrm{d}}$ & $129.9 \pm 6.8^{\mathrm{c}, \mathrm{d}}$ \\
\hline Chlorogenic acid & $101.5 \pm 12.4^{\mathrm{c}}$ & $76.7 \pm 4.91^{\mathrm{b}, \mathrm{c}}$ & $30.8 \pm 1.8^{\mathrm{c}}$ & $451.2 \pm 13.2^{\mathrm{c}, \mathrm{d}}$ & $314.3 \pm 5.6^{\mathrm{c}}$ & $190.4 \pm 5.7^{\mathrm{c}, \mathrm{d}}$ \\
\hline Catechin & $110.7 \pm 10.3^{\mathrm{b}, \mathrm{c}}$ & $81.4 \pm 5.9^{\mathrm{b}}$ & $62.6 \pm 2.5^{\mathrm{b}}$ & $551.7 \pm 10.1^{\mathrm{b}, \mathrm{c}}$ & $402.7 \pm 10.5^{\mathrm{b}}$ & $242.5 \pm 8.9^{\mathrm{c}}$ \\
\hline Trihydroxyflavone & $109.5 \pm 9.2^{\mathrm{b}, \mathrm{c}}$ & $89.0 \pm 6.3^{\mathrm{b}}$ & $34.7 \pm 1.2^{\mathrm{c}}$ & $470.3 \pm 9.8^{\mathrm{c}}$ & $382.3 \pm 9.9^{\mathrm{c}}$ & $223.4 \pm 9.1^{\mathrm{c}}$ \\
\hline Gentisic acid & $103.2 \pm 8.6^{\mathrm{c}}$ & $59.9 \pm 2.4^{\mathrm{c}}$ & $27.6 \pm 1.5^{\mathrm{c}, \mathrm{d}}$ & $412.3 \pm 10.3^{\mathrm{d}}$ & $295.6 \pm 10.1^{\mathrm{c}, \mathrm{d}}$ & $195.7 \pm 5.3^{\mathrm{c}, \mathrm{d}}$ \\
\hline Ferulic acid & $132.9 \pm 11.2^{b}$ & $77.5 \pm 2.9^{\mathrm{b}, \mathrm{c}}$ & $33.8 \pm 1.8^{\mathrm{c}}$ & $521.9 \pm 11.2^{\mathrm{c}}$ & $322.3 \pm 11.7^{\mathrm{c}}$ & $205.7 \pm 7.7^{\mathrm{c}}$ \\
\hline Protocatechuic acid & $135.7 \pm 8.3^{\mathrm{b}}$ & $73.3 \pm 3.2^{\mathrm{b}, \mathrm{c}}$ & $24.4 \pm 1.6^{\mathrm{c}, \mathrm{d}}$ & $491.2 \pm 8.7^{\mathrm{c}}$ & $273.6 \pm 10.9^{\mathrm{d}}$ & $181.4 \pm 5.3^{\mathrm{c}, \mathrm{d}}$ \\
\hline Umbelliferone & $105.8 \pm 9.8^{\mathrm{b}, \mathrm{c}}$ & $111.2 \pm 7.3^{\mathrm{b}}$ & $55.5 \pm 1.5^{\mathrm{b}}$ & $432.5 \pm 7.3^{\mathrm{c}, \mathrm{d}}$ & $250.5 \pm 11.3^{\mathrm{d}}$ & $194.5 \pm 7.8^{\mathrm{c}, \mathrm{d}}$ \\
\hline Control & $177.8 \pm 12.3^{\mathrm{a}}$ & $177.8 \pm 12.3^{\mathrm{a}}$ & $177.8 \pm 12.3^{\mathrm{a}}$ & $701.7 \pm 12.2^{\mathrm{a}}$ & $701.7 \pm 12.2^{\mathrm{a}}$ & $701.7 \pm 12.2^{\mathrm{a}}$ \\
\hline
\end{tabular}

Values (mean $\pm \mathrm{SD}$ ) with similar letters within a column do not differ significantly at $P \leq 0.05$ (Tukey's HSD test)

$D A T$ days after treatment 
Table 3 Weights (mg per five larvae) of Helicoverpa armigera larvae fed on lectin and phenyl $\beta$-glucoside-treated diet

\begin{tabular}{|c|c|c|c|c|c|c|}
\hline \multirow[t]{3}{*}{ Treatments } & \multicolumn{3}{|l|}{$5 \mathrm{DAT}$} & \multicolumn{3}{|l|}{10 DAT } \\
\hline & \multicolumn{6}{|c|}{ Concentration $\left(\mu \mathrm{g} \mathrm{mL}^{-1}\right)$} \\
\hline & 1.25 & 2.5 & 5 & 1.25 & 2.5 & 5 \\
\hline Groundnut leaf lectin & $72.4 \pm 5.8^{\mathrm{b}}$ & $54.4 \pm 2.3^{\mathrm{c}}$ & $39.8 \pm 3.5^{\mathrm{b}, \mathrm{c}}$ & $378.4 \pm 8.5^{\mathrm{c}}$ & $265.8 \pm 9.8^{\mathrm{c}}$ & $169.6 \pm 5.4^{\mathrm{c}}$ \\
\hline Concavalin & $79.7 \pm 7.4^{\mathrm{b}}$ & $63.9 \pm 4.8^{\mathrm{c}}$ & $43.5 \pm 2.7^{\mathrm{b}, \mathrm{c}}$ & $403.6 \pm 7.8^{c}$ & $332.7 \pm 11.1^{\mathrm{b}}$ & $276.8 \pm 7.9^{\mathrm{b}}$ \\
\hline Phenyl $\beta$-glucoside & $134.2 \pm 6.3^{\mathrm{a}, \mathrm{b}}$ & $106.3 \pm 7.52^{\mathrm{b}}$ & $67.6 \pm 5.5^{\mathrm{b}}$ & $478.8 \pm 6.1^{\mathrm{b}}$ & $368.8 \pm 9.7^{\mathrm{b}}$ & $309.9 \pm 9.6^{\mathrm{b}}$ \\
\hline Control & $166.9 \pm 9.7^{\mathrm{a}}$ & $166.9 \pm 9.7^{\mathrm{a}}$ & $166.9 \pm 9.7^{\mathrm{a}}$ & $678.9 \pm 11.8^{\mathrm{a}}$ & $678.9 \pm 11.8^{\mathrm{a}}$ & $678.9 \pm 11.8^{a}$ \\
\hline
\end{tabular}

Values (mean $\pm \mathrm{SD}$ ) with similar letters within a column do not differ significantly at $P \leq 0.05$ (Tukey's HSD test). In control, the values in all the columns have been mentioned to facilitate the comparison with other treatments

$D A T$ days after treatment

Fig. 1 Serine protease activity (mU $\min ^{-1} \mathrm{mg}^{-1}$ protein) of Helicoverpa armigera larvae fed on flavonoid-treated diet. Bars (mean $\pm \mathrm{SD}$ ) of same color with similar letters within a treatment are not statistically different at $P \leq 0.05$. Asterisk differences in enzyme activity on bars shows the significant across treatments at $P \leq 0.05$

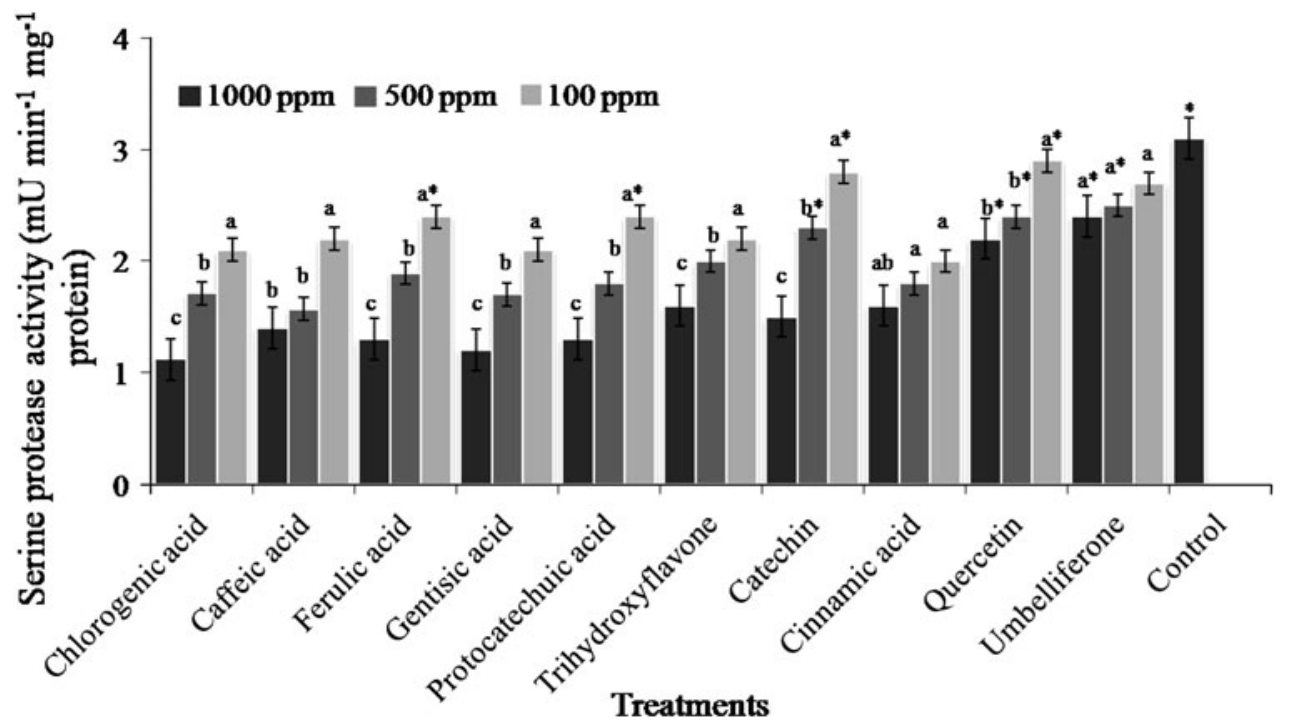

protease activity than those fed on the rest of the treatments, and the untreated control diet. The trypsin activity of larvae fed on the flavonoid-treated diet at 1,000 ppm was significantly lower than the larvae fed at 100 and $500 \mathrm{ppm}$ of the respective compounds (Fig. 2). Larvae fed on diets with $1,000 \mathrm{ppm}$ of chlorogenic acid, caffeic acid, ferulic acid, gentisic acid, protocatechuic acid and trihydroxyflavone had significantly lower trypsin activity than the larvae fed on the rest of the treatments, and the untreated diet. The GST activity of $H$. armigera larvae was significantly higher when fed on the diets treated with chlorogenic acid, caffeic acid, gentisic acid, ferulic acid, protocatechuic acid, trihydroxyflavone, catechin, cinnamic acid and umbelliferone at $1,000 \mathrm{ppm}$ than at $500 \mathrm{ppm}$, and the larvae fed on control diet (Fig. 3). Across the treatments, protocatechuic acids, trihydroxyflavone, catechin, cinnamic acid and quercetin induced higher levels than the rest of the treatments at $1,000 \mathrm{ppm}$. Larvae fed on untreated control diet had lower levels of GST activity.The $H$. armigera larvae fed on flavonoid-treated diets showed lower levels of EST activity in diets with 1,000 ppm of chlorogenic acid, caffeic acid, ferulic acid, gentisic acid, catechin, cinnamic acid and umbelliferone than those fed at 500 ppm (Fig. 4). Protocatechuic acid, gentisic acid and catechin fed larvae at $1,000 \mathrm{ppm}$ had significantly lower levels of EST activity than the rest of the treatments.

\section{Effect of GLL, ConA and phenyl $\beta$-glucoside}

$H$. armigera larvae fed on the diets containing 5 and $2.5 \mu \mathrm{g} \mathrm{mL}{ }^{-1}$ GLL showed significantly lower levels of total serine protease and trypsin activities $\left(F_{(2,8)}=19.9\right.$ and 17.3, respectively, $P<0.05)$ than those fed on diets with $1.25 \mu \mathrm{g} \mathrm{mL}^{-1} \mathrm{GLL}$ (Table 4). Similarly, larvae fed on ConAtreated diets at 5 and $2.5 \mu \mathrm{g} \mathrm{mL}^{-1}$ concentration had significantly reduced total serine protease and trypsin activities $(P<0.05)$. Larvae fed on the phenyl $\beta$-glucoside-treated diet showed reduced serine protease activity at 5 and $2.5 \mu \mathrm{g} \mathrm{mL}{ }^{-1}$ concentrations $\left(F_{(2,8)}=11.2, P<0.05\right)$, but did not exhibit any significant differences in trypsin activity across 
Fig. 2 Trypsin activity ( $\mu \mathrm{mol} \mathrm{min} \mathrm{mg}^{-1} \mathrm{mg}^{-1}$ protein) of Helicoverpa armigera larvae fed on flavonoid-treated diet. Bars (mean $\pm \mathrm{SD}$ ) of same color with similar asterisks within a treatment are not statistically different at $P \leq 0.05$. Asterisks on bars show the significant differences in enzyme activity across treatments at $P \leq 0.05$

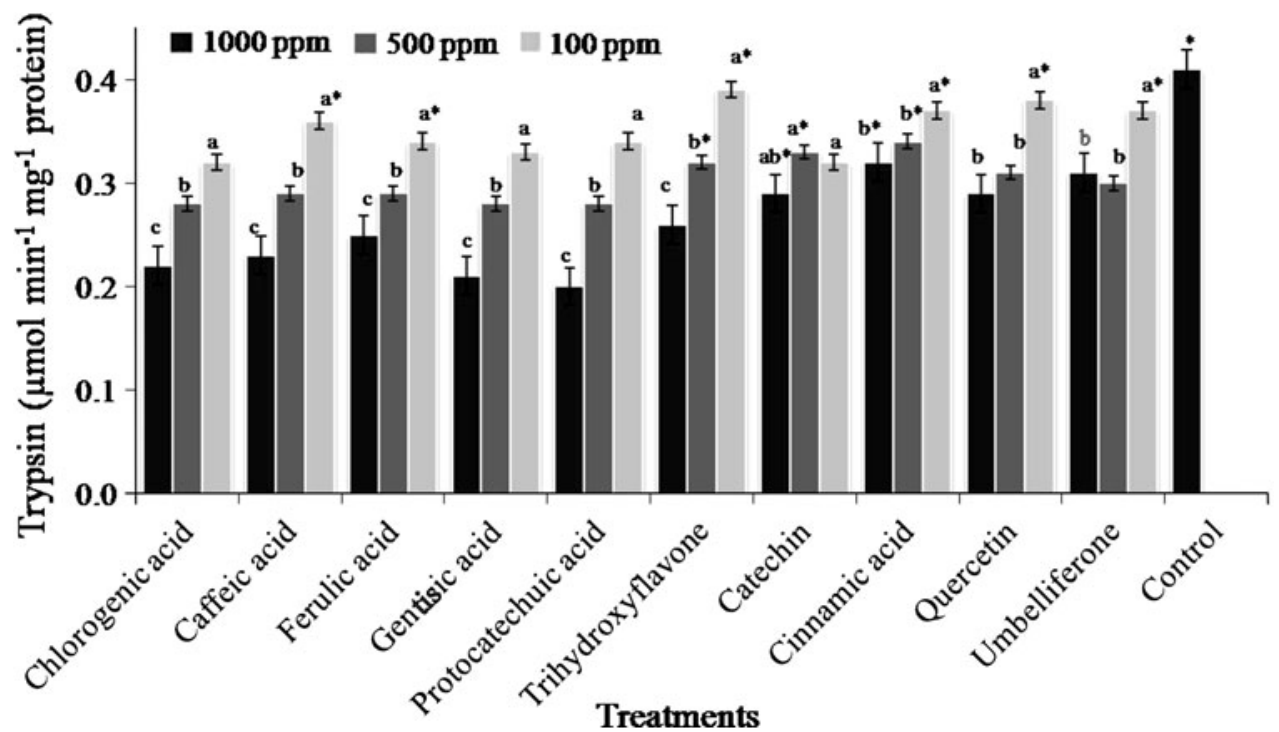

Fig. 3 Glutathione- $S$ transferase (GST) activity ( $\mu \mathrm{mol} \mathrm{CDNB} \min ^{-1} \mathrm{mg}^{-1}$ protein) of Helicoverpa armigera larvae fed on flavonoid-treated diet. Bars (mean $\pm \mathrm{SD}$ ) of same color with similar letters within a treatment are not statistically different at $P \leq 0.05$. Asterisks on bars show the significant differences in enzyme activity across treatments at $P \leq 0.05$

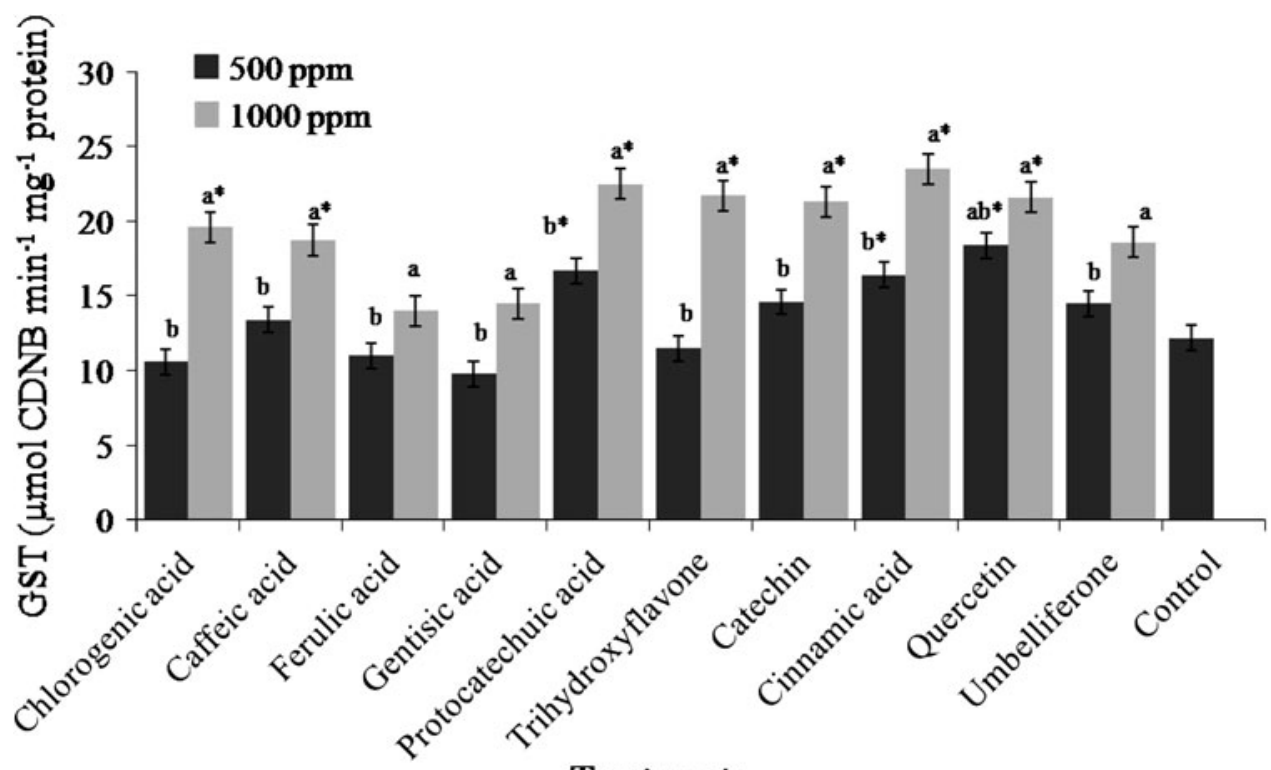

\section{Treatments}

concentrations. Across treatments, larvae fed on a GLL-treated diet at 5 and $2.5 \mu \mathrm{g} \mathrm{mL}^{-1}$ concentrations had significantly reduced serine protease and trypsin activities $(P<0.05)$.

The $H$. armigera larvae fed on GLL showed increased GST activity at 2.5 and $5 \mu \mathrm{g} \mathrm{mL}^{-1}$ concentrations as compared to those fed on a diet with $1.25 \mu \mathrm{g} \mathrm{mL}^{-1}$ concentrations $\left(F_{(2,8)}=14.5, P<0.05\right)$ (Table 5). Although there was an increase in GST activity of the larvae fed on ConA and phenyl $\beta$-glucoside-treated diets, the differences were not statistically significant $(P>0.05)$. Across the treatments, no significant differences were observed in GST activity of $H$. armigera larvae in all the concentrations tested $(P>0.05)$.
The H. armigera larvae fed on the GLL and ConAtreated diets showed reduced EST activity at $5 \mu \mathrm{g} \mathrm{mL}$ concentration $\left(F_{(2,8)}=7.8\right.$ and 9.9, respectively, $\left.P<0.05\right)$ compared to those fed on diets with 2.5 and $1.25 \mu \mathrm{g} \mathrm{mL}$ concentrations (Table 5). The larvae fed on diets containing phenyl $\beta$-glucoside did not show any significant effect on EST activity of $H$. armigera larvae $(P>0.05)$. Across treatments, the larvae fed on the GLL-treated diet at $5 \mu \mathrm{g} \mathrm{mL}^{-1}$ showed significantly reduced EST activity $\left(F_{(3,11)}=23.5, P<0.05\right)$ as compared to those fed on ConA and phenyl $\beta$-glucoside-treated diets. There were no significant differences in EST activity of the larvae fed on diets with 2.5 and $1.25 \mu \mathrm{g} \mathrm{mL}^{-1}(P>0.05)$. 
Fig. 4 Esterase (EST) activity ( $\mu$ mol 1-naphthol $\mathrm{min}^{-1} \mathrm{mg}^{-1}$ protein) of Helicoverpa armigera larvae fed on flavonoid-treated diet. Bars (mean $\pm \mathrm{SD}$ ) of same color with similar letters within a treatment are not statistically different at $P \leq 0.05$. Asterisks on bars show the significant differences in enzyme activity across treatments at $P \leq 0.05$

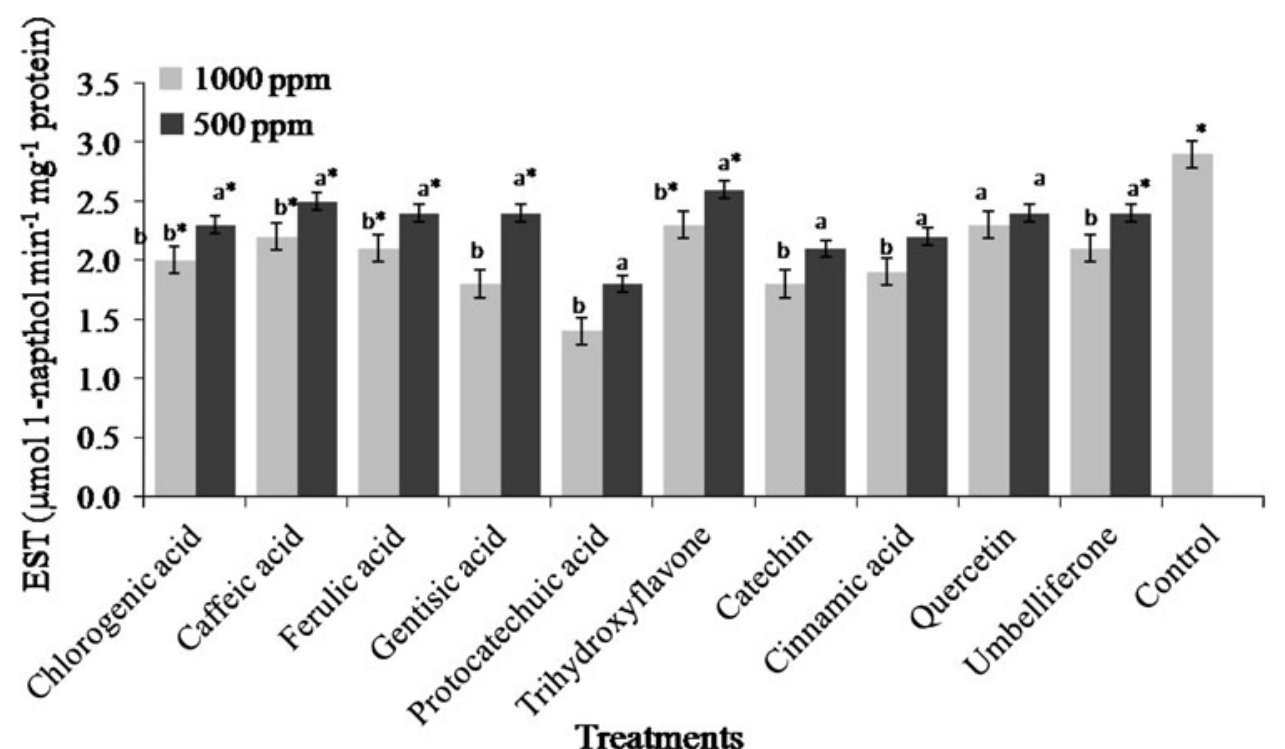

Table 4 Total serine protease and trypsin activities of Helicoverpa armigera larvae fed on lectin and phenyl $\beta$-glucoside-treated diet at 10 DAT

\begin{tabular}{|c|c|c|c|c|c|c|}
\hline \multirow[t]{3}{*}{ Treatments } & \multicolumn{3}{|c|}{ Serine protease $\left(\mathrm{mU} \mathrm{min} \mathrm{mi}^{-1} \mathrm{mg}^{-1}\right.$ protein) } & \multicolumn{3}{|c|}{ Trypsin $\left(\mu \mathrm{mol} \mathrm{min}{ }^{-1} \mathrm{mg}^{-1}\right.$ protein $)$} \\
\hline & \multicolumn{6}{|c|}{ Concentration $\left(\mu \mathrm{g} \mathrm{mL}^{-1}\right)$} \\
\hline & 1.25 & 2.5 & 5 & 1.25 & 2.5 & 5 \\
\hline Groundnut leaf lectin & $1.45 \pm 0.02^{\mathrm{a}}$ & $1.17 \pm 0.01^{\mathrm{b}}$ & $1.09 \pm 0.02^{\mathrm{b}}$ & $0.32 \pm 0.001^{\mathrm{a}}$ & $0.17 \pm 0.001^{\mathrm{b}}$ & $0.15 \pm 0.001^{\mathrm{b}}$ \\
\hline Concavalin & $1.56 \pm 0.04^{\mathrm{a}}$ & $1.27 \pm 0.02^{\mathrm{b}}$ & $1.10 \pm 0.04^{\mathrm{b}}$ & $0.33 \pm 0.006^{\mathrm{a}}$ & $0.25 \pm 0.004^{\mathrm{a}, \mathrm{b}}$ & $0.23 \pm 0.003^{\mathrm{a}, \mathrm{b}}$ \\
\hline Phenyl $\beta$-glucoside & $1.68 \pm 0.04^{\mathrm{a}}$ & $1.32 \pm 0.09^{\mathrm{b}}$ & $1.21 \pm 0.03^{\mathrm{b}}$ & $0.29 \pm 0.007^{\mathrm{a}, \mathrm{b}}$ & $0.27 \pm 0.001^{\mathrm{a}, \mathrm{b}}$ & $0.25 \pm 0.000^{\mathrm{a}, \mathrm{b}}$ \\
\hline Control & $1.63 \pm 0.05^{\mathrm{a}}$ & $1.63 \pm 0.05^{\mathrm{a}}$ & $1.63 \pm 0.05^{\mathrm{a}}$ & $0.35 \pm 0.009^{\mathrm{a}}$ & $0.35 \pm 0.009^{\mathrm{a}}$ & $0.35 \pm 0.009^{\mathrm{a}}$ \\
\hline
\end{tabular}

Values (mean $\pm \mathrm{SD}$ ) with similar letters within a column do not differ significantly at $P \leq 0.05$ (Tukey's HSD test). In control, the values in all the columns have been mentioned to facilitate the comparison with other treatments

$D A T$ days after treatment

Table 5 GST and EST activities of Helicoverpa armigera larvae fed on lectin and phenyl $\beta$-glucoside-treated diet at 10 DAT

\begin{tabular}{|c|c|c|c|c|c|c|}
\hline \multirow[t]{3}{*}{ Treatments } & \multicolumn{3}{|c|}{ GST activity ( $\mu$ mol CDNB min- $1 \mathrm{mg}-1$ protein) } & \multicolumn{3}{|c|}{ EST ( $\mu$ mol 1-naphthol $\min ^{-1} \mathrm{mg}^{-1}$ protein) } \\
\hline & \multicolumn{6}{|c|}{ Concentration $\left(\mu \mathrm{g} \mathrm{mL}^{-1}\right)$} \\
\hline & 1.25 & 2.5 & 5 & 1.25 & 2.5 & 5 \\
\hline Groundnut leaf lectin & $19.5 \pm 1.5^{\mathrm{ab}}$ & $25.0 \pm 2.6^{\mathrm{ab}}$ & $24.9 \pm 2.2^{\mathrm{a}}$ & $3.7 \pm 0.08^{\mathrm{b}}$ & $3.8 \pm 0.07^{\mathrm{b}}$ & $2.8 \pm 0.08^{\mathrm{ab}}$ \\
\hline Concavalin & $20.1 \pm 4.1^{\mathrm{a}}$ & $23.3 \pm 1.9^{\mathrm{a}}$ & $23.6 \pm 2.7^{\mathrm{a}}$ & $4.3 \pm 0.07^{\mathrm{b}}$ & $3.9 \pm 0.03^{\mathrm{b}}$ & $3.2 \pm 0.06^{\mathrm{b}}$ \\
\hline Phenyl $\beta$-glucoside & $25.5 \pm 2.1^{\mathrm{a}}$ & $26.7 \pm 3.0^{\mathrm{a}}$ & $24.6 \pm 1.2^{\mathrm{a}}$ & $5.0 \pm 0.04^{\mathrm{a}}$ & $4.6 \pm 0.09^{\mathrm{ab}}$ & $4.3 \pm 0.04^{\mathrm{a}}$ \\
\hline Control & $20.0 \pm 2.3^{\mathrm{a}}$ & $20.0 \pm 2.3^{\mathrm{a}}$ & $20.0 \pm 2.3^{\mathrm{a}}$ & $5.8 \pm 0.02^{\mathrm{a}}$ & $5.8 \pm 0.02^{\mathrm{a}}$ & $5.8 \pm 0.02^{\mathrm{a}}$ \\
\hline
\end{tabular}

Values (mean $\pm \mathrm{SD}$ ) carrying same letter(s) within a column are not significantly different at $P \leq 0.05$ (Tukey's HSD test). In control, the values in all the columns have been mentioned to facilitate the comparison with other treatments

$D A T$ days after treatment, GST glutathione-S-transferase, EST esterase

\section{Discussion}

Flavonoids are important plant secondary metabolites involved in defense against a number of stresses including herbivory (Stevenson et al. 1993; Treutter 2006; Sharma et al. 2009). Plants contain more than 5,000 flavonoids, which play a central role in plant-environment interactions
(Treutter 2006). Flavonoids and isoflavonoids directly affect the insect behavior, growth and development (Stevenson et al. 1993; Simmonds 2003). Summers and Felton (1994) reported the midgut toxicity in insect pests fed on diets containing chlorogenic and caffeic acid. Various flavonoids including isorhamnetin-3-sophoroside-7-glucoside and kaempferol-3,7-diglucoside have been reported as 
feeding deterrents against Mamestra configurata (Walk.) (Onyilagha et al. 2004).

The present study revealed that chlorogenic acid, caffeic acid and protocatechuic acid when incorporated into an artificial diet at 1,000 ppm were more toxic to $H$. armigera larvae at 10 DAT than quercetin, catechin, cinnamic acid, trihydroxyflavone, gentisic acid, ferulic acid and umbelliferone. The weights of the larvae fed on flavonoid-treated diets were significantly lower as compared to those fed on the control diet. In addition, total serine protease and trypsin activities were reduced in $H$. armigera larvae fed on diets treated with chlorogenic acid, caffeic acid, ferulic acid, trihydroxyflavone, gentisic acids and cinnamic acid at 1,000 ppm. The GST activity increased in larvae fed on diets treated with $1,000 \mathrm{ppm}$ of these compounds. EST activity showed a reduction in $H$. armigera larvae fed on flavonoid-treated diets at 1,000 ppm. However, the levels of reduction varied across the treatments. Our results are in line with earlier reports, which have shown a significant increase in GST activity in larvae fed on natural host plant diet with prooxidant allelochemicals (Vanhaelen et al. 2003; Krishnan and Kodrík 2006) and/or fed on the artificial diet containing plant allelochemicals (Morimoto et al. 2000; Atteyat et al. 2012). Leaf discs treated with various flavonoids also reduce larval growth and development of Trichoplusia ni (Hub.) (Sharma and Norris 1991). A considerable effect of flavonoids such as quercetin, chlorogenic acid and rutin from Arachis spp. on larval, pupal and moth deformities of Spodoptera litura Fab. has been observed earlier by Mallikarjuna et al. (2004). Caffeic and chlorogenic acids are highly toxic to insect pests and have been reported to cause gut toxicity due to protein oxidation and free ion release (Summers and Felton 1994). Chlorogenic acid reduces the nutritional quality of plant tissues by decreasing their digestibility due to the binding of chlorogenoquinone, an oxidative product of chlorogenic acid, to free amino acids and proteins (Felton et al. 1992), and reduces the growth and development of many insect pests including T. ni (Beninger et al. 2004), Heliothis zea (Bod.) (Isman and Duffey 1982; Felton and Duffey 1990), leaf beetles, leaf hoppers and aphids (Ikonen et al. 2002; Jassbi 2003). Sharma and Norris (1991) have reported the antifeedant and antibiotic effects of daidzein, glyceollins, sojagol and coumestrol in soybean against $T$. $n i$.

Lectins are regarded as potent plant defensive proteins that bind to soluble carbohydrates or to carbohydrate of the glycoproteins, and limit their availability to insects (Peumans and Vandamme 1995), thus depriving the insects from essential nutrients and resulting in reduced growth and development. There are a number of reports that have shown the deleterious effects of lectins on insect pests (Murdock et al. 1990; Czapla and Lang 1990; Zhu-Salzman et al. 1998; Gatehouse et al. 1999; Arora et al. 2004; Shukla et al. 2005).
Lectins are also induced in plants in response to herbivory and/or elicitor application and play an important role in signaling the transduction pathways in plants (Van Damme et al. 2003; Lannoo et al. 2006). Our results showed that larval growth and development were significantly reduced in $H$. armigera larvae fed on a diet with GLL and ConA at $5 \mu \mathrm{g} \mathrm{mL}^{-1}$ compared to the larvae fed at 2.5 and $1.25 \mu \mathrm{g} \mathrm{mL}^{-1}$ concentrations. Larvae fed on lectin-treated diets exhibited lower larval weights at 5 DAT; however, at 10 DAT, weights of the larvae fed on phenyl $\beta$-glucoside were on par with those fed on the lectin-treated diets. Moreover, there was a considerable reduction in the total serine protease and trypsin activities of $H$. armigera larvae fed on GLL, ConA and phenyl $\beta$-glucoside-treated diets at $5 \mu \mathrm{g} \mathrm{mL}^{-1}$. However, reduction in trypsin activity was greater in larvae fed on the GLL-treated diet than the larvae fed on the ConA and phenyl $\beta$-glucoside-treated diets at $5 \mu \mathrm{g} \mathrm{mL}^{-1}$. The GST and EST activities were also altered significantly. Significant inhibitory activity on insect growth has been observed in Callosobruchus maculatus (F.) fed on a diet treated with Maclura pomifera (Raf.) Schneid., derived lectin and galactose-binding peanut lectin (Murdock et al. 1990). Jacalin and M. pomifera lectin reduced the larval growth of Diabrotica undecimpunctata Barber (Czapla and Lang 1990). ConA lectin, when incorporated in the artificial diet, resulted in $90 \%$ larval mortality of tomato moth, Lacanobia oleracea (L.), and also reduced the size of M. persicae by about $30 \%$. Expression of ConA in potato plants reduced the larval weight by $45 \%$ (Gatehouse et al. 1999). Phenolic glucosides have been reported as important defensive components against insect pests in Populus (Bryant et al. 1987; Boeckler et al. 2011). This study shows that flavonoids such as chlorogenic acid, caffeic acid, gentisic acid, trihydroxyflavone, catechin and protocatechuic acid, and lectins, GLL and ConA, are highly toxic to $H$. armigera and can form an important component of insect pest management against $H$. armigera.

Acknowledgments We are thankful to entomology staff at ICRISAT especially, Mr. Rajendra S. Munghate, Mr. Suraj P. Shrama and Mr. VV Rao for their help in carrying out the experiments.

\section{References}

Arora A, Sharma HC, Dhillon MK, Chakraborty D, Das S, Romeis J (2004) Impact of Allium sativum leaf lectin on the Helicoverpa armigera larval parasitoid Campoletis chlorideae. SAT ejournal $3(1): 41-43$

Atteyat M, Abu-Romann S, Abu-Darwish M, Ghabeish I (2012) Impact of flavonoids against woolly apple aphid, Eriosoma lanigerum (Hausmann) and its sole parasitoid, Aphelinus mali (Hald.). J Agric Sci 4:227-236

Ballhorn DJ, Kautz S, Jensen M, Schmitt I, Heil M, Hegeman AD (2011) Genetic and environmental interactions determine plant defenses against herbivores. Ecology 99:313-326 
Barakat A, Bagniewska-Zadworna A, Frost CJ, Carlson JE (2010) Phylogeny and expression profiling of CAD and CAD-like genes in hybrid Populus $(P$. deltoides $\times P$. nigra): evidence from herbivore damage for subfunctionalization and functional divergence. BMC Plant Biol 10:100

Beninger CW, Abou-Zaid MM, Kistner ALE, Hallett RH, Iqbal MJ, Grodzinski B, Hall JC (2004) A flavanone and two phenolic acids from Chrysanthemum morifolium with phytotoxic and insect growth regulating activity. J Chem Ecol 30:589-606

Boeckler GA, Gershenzon J, Unsicker SB (2011) Phenolic glycosides of the Salicaceae and their role as anti-herbivore defenses. Phytochemistry 72:1497-1509

Boerjan W, Ralph J, Baucher M (2003) Lignin biosynthesis. Annu Rev Plant Biol 54:519-546

Bryant JP, Clausen TP, Reichardt PB, McCarthy MC, Werner RA (1987) Effect of nitrogen fertilization upon the secondary chemistry and nutritional value of quaking aspen (Populus tremuloides Michx.) leaves for the large aspen tortrix (Choristoneura conflictana ([Walker]). Oecologia 73:513-517

Chakraborti D, Sarkar A, Mondal HA, Das S (2009) Tissue specific expression of potent insecticidal, Allium sativum leaf agglutinin (ASAL) in important pulse crop, chickpea (Cicer arietinum L.) to resist the phloem feeding Aphis craccivora. Transgenic Res 18:529-544. doi:10.1007/s11248-009-9242-7

Czapla TH, Lang BA (1990) Effect of plant lectins on the larval development of European corn borer (Lepidoptera: Pyralidae) and southern corn rootworm Coleoptera: Chrysomelidae). J Econ Entomol 83:2480-2485

Felton GW, Duffey SS (1990) Inactivation of baculovirus by quinones formed in insect damaged plant-tissues. $J$ Chem Ecol $16: 1221-1236$

Felton GW, Donato KK, Broadway RM, Duffey SS (1992) Impact of oxidized plant phenolics on the nutritional quality of dietaryprotein to a noctuid herbivore, Spodoptera exigua. J Insect Physiol 38:277-285

Gatehouse AMR, Davison GM, Stewart JN, Gatehouse LN, Kumar A, Geoghegan IE, Birch ANE, Gatehouse JA (1999) Concanavalin A inhibits development of tomato moth (Lacanobia oleracea) and peach-potato aphid (Myzus persicae) when expressed in transgenic potato plants. Mol Breeding 5:153-165

Grayer RJ, Kimmins FM, Padgham DE, Harborne JB, Ranga Rao DV (1992) Condensed tannin levels and resistance in groundnuts (Arachis hypogoea L.) against Aphis craccivora (Koch). Phytochemistry 31:3795-3799

Habig WH, Pabst MJ, Jakoby WB (1974) Glutathione-S-transferases. The first enzymatic step in mercapturic acid formation. J Biol Chem 249:7130-7139

He J, Chen F, Chen S, Lv G, Deng Y, Fang Z, Guan Z, He C (2011) Chrysanthemum leaf epidermal surface morphology and antioxidant and defense enzyme activity in response to aphid infestation. J Plant Physiol 168:687-693

Hegedus D, Baldwin D, O'Grady M, Braun L, Gleddie S, Sharpe A, Lydiate D, Erlandson M (2003) Midgut proteases from Mamestra configurata (Lepidoptera: Noctuidae) larvae: characterization, cDNA cloning, and expressed sequence tag analysis. Arch Insect Biochem Physiol 53:30-47

Heil M (2008) Indirect defence via tritrophic interactions. New Phytol 178:41-61

Ikonen A, Tahvanainen J, Roininen H (2002) Phenolic secondary compounds as determinants of the host plant preferences of the leaf beetle Agelastica alni. Chemoecology 12:125-131

Isman MB, Duffey SS (1982) Toxicity of tomato phenolic compounds to the fruitworm, Heliothis zea. Entomol Exp Appl 31:370-376

Jassbi AR (2003) Secondary metabolites as stimulants and antifeedants of Salix integra for the leaf beetle Plagiodera versicolora. Zeitschrift Fur Natur C 58:573-579
Karban R, Baldwin IT (1997) Induced responses to herbivory. University of Chicago Press, Chicago

Krishnan N, Kodrík D (2006) Antioxidant enzymes in Spodoptera littoralis (Boisduval): are they enhanced to protect gut tissues during oxidative stress? J Insect Physiol 52:11-20

Lannoo N, Peumans WJ, Van Damme EJM (2006) The presence of jasmonate-inducible lectin genes in some but not all Nicotiana species explains a marked intragenus difference in plant responses to hormone treatment. J Exp Bot 57:3145-3155

Maffei ME, Mithofer A, Boland W (2007) Insects feeding on plants: rapid signals and responses preceding the induction of photochemical release. Phytochemistry 68:2946-2959

Mallikarjuna N, Kranthi KR, Jadhav DR, Kranthi S, Chandra S (2004) Influence of foliar chemical compounds on the development of Spodoptera litura (Fab.) in interspecific derivatives of groundnut. J Appl Entomol 128:321-328

Morimoto M, Kumeda S, Komai K (2000) Insect antifeedant flavonoids from Gnaphalium affine D. Don. J Agric Food Chem 48:1888-1891

Murdock LL, Huesing JA, Nielsen SS, Pratt RC, Shade RE (1990) Biological effects of plant lectins on the cowpea weevil. Phytochemistry 29:85-89

Narayanamma LV, Sharma HC, Gowda CLL, Sriramulu M (2008) Incorporation of lyophilized leaves and pods into artificial diets to assess the antibiosis component of resistance to pod borer, Helicoverpa armigera (Lepidoptera: Noctuidae) in chickpea. Int J Tropical Insect Sci 27:191-198

Onyilagha JC, Lazorko J, Gruber MY, Soroka JJ, Erlandson MA (2004) Effect of flavonoids on feeding preference and development of the crucifer pest Mamestra configurata Walker. J Chem Ecol 30:109-124

Perlmann G, Lorand L (eds) (1970) Proteolytic enzymes, 2nd edn, vol 19. Methods in enzymology. Academic Press, New York, pp 770-782

Peumans WJ, Vandamme EJM (1995) Lectins as plant defense proteins. Plant Physiol 109:347-352

Saha P, Majumder P, Dutta I, Ray T, Roy SC, Das S (2006) Transgenic rice expressing Allium sativum leaf lectin with enhanced resistance against sap-sucking insect pests. Planta 223:1329-1343

Salvador MC, Boica AL Jr, de Oliveira MCN, da Graca JP, da Silva DM, Hoffman-Campo CB (2010) Do different casein concentrations increase the adverse effect of rutin on the biology of Anticarsia gemmatalis Hübner (Lepidoptera: Noctuidae)? Neotropical Entomol 39:774-783

Sharma HC, Norris DM (1991) Chemical basis of resistance in soya bean to cabbage looper, Trichoplusia ni. J Sci Food Agric 55:353-364

Sharma HC, Pampathy G, Dhillon MK, Ridsdill-Smith JT (2005) Detached leaf assay to screen for host plant resistance to Helicoverpa armigera. J Econ Entomol 98(2):568-576

Sharma HC, Sujana G, Rao DM (2009) Morphological and chemical components of resistance to pod borer, Helicoverpa armigera in wild relatives of pigeonpea. Arthropod-Plant Interact 3(3):151-161

Shukla S, Arora R, Sharma HC (2005) Biological activity of soybean trypsin inhibitor and plant lectins against cotton bollworm/ legume pod borer, Helicoverpa armigera. Plant Biotech 22:1-6

Simmonds MSJ (2003) Flavonoid-insect interactions: recent advances in our knowledge. Phytochemistry 64:21-30

Simmonds MSJ, Stevenson PC (2001) Effects of isoflavonoids from Cicer on larvae of Heliocoverpa armigera. J Chem Ecol 27:965-977

Stevenson PC, Blaney WL, Simmonds MSJ, Wightman JA (1993) The identification and characterization of resistance in wild species of Arachis to Spodoptera litura (Lepidoptera: Noctuidae). Bull Entomol Res 83:421-429 
Summers CB, Felton GW (1994) Prooxidant effects of phenolic acids on the generalist herbivore Helicoverpa zea (Lepidoptera: Noctuidae): potential mode of action for phenolic compounds in plant anti-herbivore chemistry. Insect Biochem Mol Biol 24:943-953

Treutter D (2006) Significance of flavonoids in plant resistance: a review. Environ Chem Lett 4:147-157

Usha Rani P, Jyothsna Y (2010) Biochemical and enzymatic changes in rice as a mechanism of defense. Acta Physiol Plant 32:695-701

Van Damme EJM, Lannoo N, Fouquaert E, Peumans WJ (2003) The identification of inducible cytoplasmic/nuclear carbohydratebinding proteins urges to develop novel concepts about the role of plant lectins. Glycoconj J 20:449-460

van Loon JJA, Wang CZ, Nielsen JK, Gols R, Qiu YT (2002) Flavonoids from cabbage are feeding stimulants for diamondback moth larvae additional to glucosinolates: chemoreception and behavior. Entomol Exp Appl 104:27-34
Vandenborre G, Smagghe G, Van Damme EJM (2011) Plant lectins as defense proteins against phytophagous insects. Phytochemistry. doi:10.1016/j.phytochem.2011.02.024

Vanhaelen N, Haubruge E, Lognay G, Francis F (2003) Hoverfly glutathione $S$-transferases and effect of Brassicaceae secondary metabolites. Pest Biochem Physiol 71:170-177

War AR, Paulraj MG, Ignacimuthu S, Sharma HC (2012) Defensive responses in groundnut against chewing and sap sucking insects. J Plant Growth Regul. doi: 10.1007/s00344-012-9294-4

Zagrobelny M, Bak S, Rasmussen AV, Jorgensen B, Naumann CM, Moller BL (2004) Cyanogenic glucosides and plant-insect interactions. Phytochemistry 65:293-306

Zhu-Salzman K, Shade RE, Koiwa H, Salzman RA, Narasimhan M, Bressan RA, Hasegawa PM, Murdock LL (1998) Carbohydrate binding and resistance to proteolysis control insecticidal activity of Griffonia simplicifolia lectin II. Proc Natl Acad Sci USA 95:15123-15128 